\title{
STUDIES ON THE JAPANESE MARINE FUNGI LIGNICOLOUS GROUP II.
}

\author{
$\operatorname{AUTHOR}(\mathrm{S})$ : \\ Tubaki, Keisuke
}

\section{CITATION:}

Tubaki, Keisuke. STUDIES ON THE JAPANESE MARINE FUNGI LIGNICOLOUS GROUP II.. PUBLICATIONS OF THE SETO MARINE BIOLOGICAL LABORATORY 1968, 15(5): 357-372

\section{ISSUE DATE:}

1968-03-25

URL:

http://hdl.handle.net/2433/175483

RIGHT: 


\title{
STUDIES ON THE JAPANESE MARINE FUNGI LIGNICOLOUS GROUP II.*
}

\author{
KeISUKE TUBAKI \\ Institute for Fermentation, Juso-Nishino-cho, Higashiyodogawa-ku, \\ Osaka, Japan
}

With Plates XII-XIX and 3 Text-figures

In the previous paper, two species of Ascomycetes and four of Fungi Imperfecti from Japanese marine habitats were reported: namely, Ceriosporopsis halima, Corollospora maritima, Cirrenalia macrocephala, Culcitalna achraspora, Papulaspora halima and Zalerion maritima. As seen in the previous paper, it appears that Ceriosporopsis halima develops perithecia easily on the unsupplemented seawater (sw) agar medium with sparse mycelium and, in this condition, the ascospores lack the appendages completely. Normal appendages of Cer. halima and Cor. maritima can be stained clearly by toluidine-blue, and this shows that such gelatinous appendages are presumably composed of acid-polysaccharide substances. The present paper is a continuation and expansion of the above-mentioned work on the marine fungi, and other Ascomycetes and Fungi Imperfecti are reported at the same time. As in the previous paper of the series, the major emphasis is placed on the morphological structure and characterization of the fructifications. Up to the present, about ten collecting stations are established around the Japan Islands, being mostly restricted to the southern half of Japan. A geographical distribution map of the marine fungi around Japan will appear in next paper, and the discussion on physiological properties is reserved for another future paper.

The collecting method adopted in the present study is basically the same as that of the previous one, using the polyethylene-net containing five series of wood panels of balsa, Abies firma, Cryptomeria japonica, Paulownia fomentosa and Phyllostachys pubescens. The collection of the drift woods on the seashore was also made. In addition to Iwaya, Oshoro and Akkeshi, as described in the previous paper, the following collecting places were added: Shirahama, Tottori, Tomo, Amakusa, and Tane Island (Fig. 1). Because of the fact that lignicolous marine fungi are more abundant during spring to autumn as would be expected, the collections were mostly made during the period of May through December. Toluidine-blue is used for staining ascospore-appendages because these appendages, especially of gelationus substances, can be clearly detected under this staining as already described. Phase-

\footnotetext{
* This publication is part of a paper read to the first Japan-U.S. Seminar on Marine Microbiology, The Eleventh Pacific Science Congress, in Tokyo on August 19, 1966.
}

Publ. Seto Mar. Biol. Lab., XV (5), 357-372, 1968. (Article 23) 


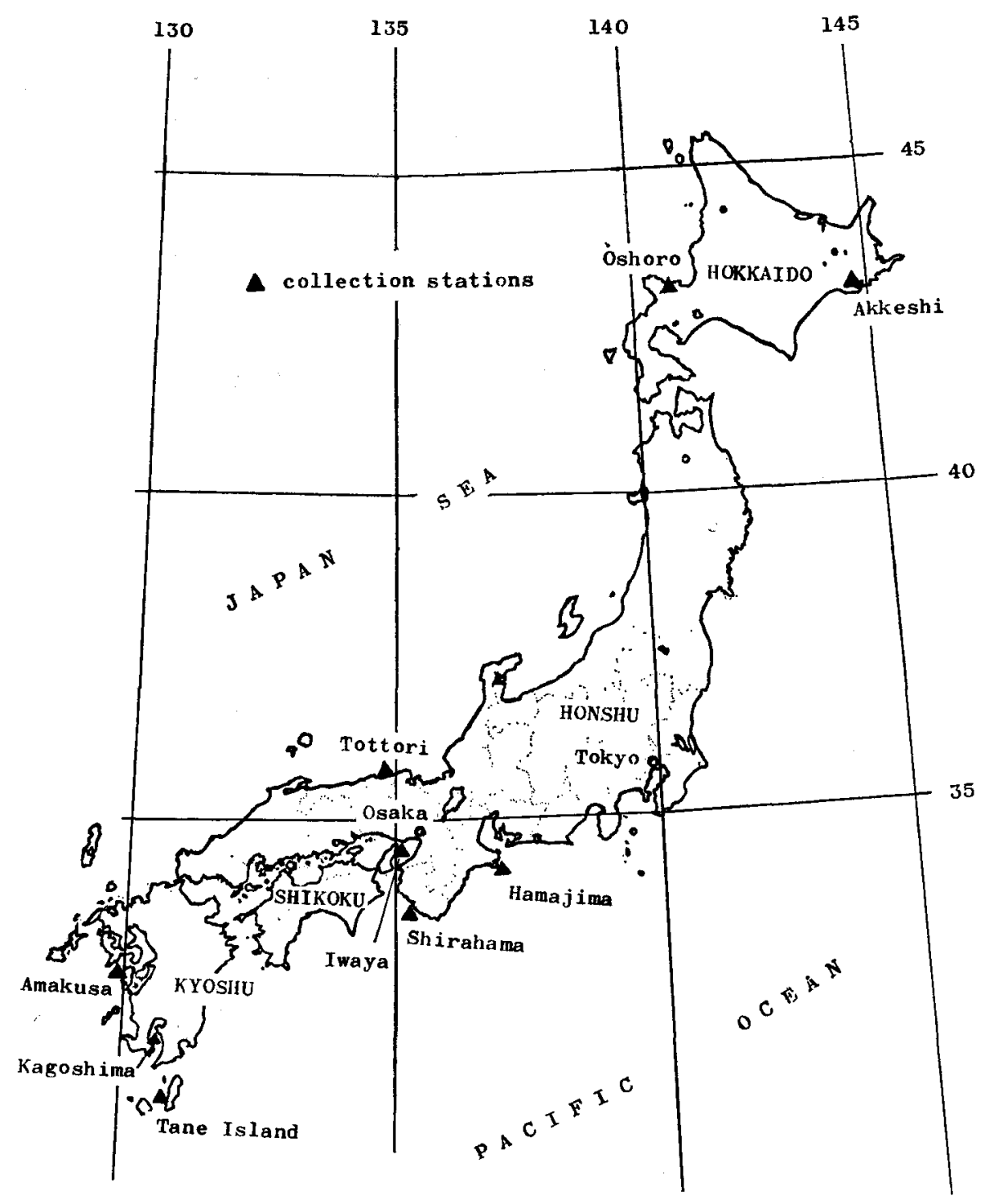

Fig. 1. Map of Japan with collection stations. 
contrast microscope was also useful for examining the appendages.

\title{
SPECIES EXAMINED
}

\author{
Ascomycetes \\ Antennospora quadricornuta (CRIBB et CRIBB) JoHnson
}

(PI. XII, A)

Johnson, in Jour Elisha Mitchell Sci. Soc. 74: 46 (1958)

syn. Halosphaeria quadricornuta CRIBB et $\mathrm{C}_{\mathrm{R}} \mathrm{BB}$

Perithecia mostly innate, globose or subglobose, becoming exposed through erosion of substratum, membranaceous, 50-240 $\times 20-50 \mu$, dark brown to almost black; neck papilliform or short cylindric. Paraphyses present, simple. Asci clavate or elongate clavate, deliquescent, 8-spored. Ascospores ellipsoidal or elongate ellipsoid, 2-celled, often curved, with a slight constriction at septa, appendaged, 2celled, often curved, with a slight constriction at septa, appendaged, 23-35 $\times 9-12 \mu$, hyaline; appendages subterminal, in pairs at each end, these pairs being at the right angle to one another, acuminate and rigid, 25-35 $\mu$ long; non-gelatinous (Pl. XII-A).

Growth on SW agar (seawater agar), good, cottony, greyish brown-colored; reverse dark blue-black to black; good growth at $30^{\circ} \mathrm{C}$.

Hab. Drift wood, Tane Island, Oct., 1966 (TN-4-1).

Though the present species was originally described in the genus Halosphaeria (1956), Johnson (1958) reasigned it to Meyers' genus Antennospora (1957) because the species of Halosphaeria should have ascospores in which appendages are equatorial, terminal, gelatinous and not paired. The present fungus coincided with the Type (OLD. Mar. Fungi No. 81) of the species which was kindly offered from Dr. A.B. CRIBB, University of Queensland. Because the appendages are not gelatinous, they can be easily detected under the ordinal transmitted light. The present species is known as a significant member of the lignicolous mycota of warmer marine habitats (Meyers \& Reynold, 1960) and the present collection was also made around Tane Island, one of the subtropical islands of Japan.

\section{Corollospora trifurcata (HÖHNK) KOHLMEYER}

(Pl. XII,B-C; XVII, A-B)

Kohlmeyer, in Berich. Deutsch. Bot. Gesell. 75: 126 (1962)

syn. Arenariomyces trifurcatus HöHNk; Halosphaeria trifurcata (HöHNK) CRIBB et CRIBB

Perithecia small, arenicolous and superficial on sand grains, scattered or often gregarious, globose or subglobose, mostly with a broad base; neck papilliform, reaches 
a length of 25-30 $\mu$; fuscous, dark brown to almost black, carbonaceous, 10 in diam.; wall finely echinulate or rough (Pl. XVII:A, B). Aparaphysat elongate clavate or irregularly fusiform, deliquescent, 8-spored, $70-80 \times 2$ Ascospores oblong or ellipsoidal, 2-celled, with or without constriction a guttulated, covered by a sheath, 24-30×7-10 $\mu$, hyaline; appendages usuc number at each end, subterminal, not-gelatinous, curved or bent towards end, tapering upward, 20-30 $\mu$ long, 1.5-2 $\mu$ in diam. at base (Pl. XII-B).

Growth on SW agar restricted, olive grey; reverse dark olive to almo growth is best at $25^{\circ} \mathrm{C}$.

Hab. Sand grains on drift wood or other substrata, Moroyose, Tottc 1966 (148-49-1, 148-48-4) and Oshoro, Hokkaido, Oct. 1966 (HO-39-2).

Fructifications developed mostly on the sand grains and the vegetative were attached to the wood-substratum. Ascospores poorly or hardly germi SW agar, malt agar or other several kinds of media, but germinate regularl, medium containing $1 \%$ of yeast extract. The nature of the appendages was $c$ in detail by Johnson (1963). It was in the HöHNk's report that the growt present species on sand particles was mentioned; Johnson \& Sparoow sta assumed that only the fructifications develop on the particles and that the ve hyphae are in some way attached to or embedded in a cellulosic substratum this is not apparent in HöHnK's paper." Johnson's consideration that the ve hyphae are attached to the wood substratum is true as mentioned alread. ecological characteristic seems to be important in this species. Recentl: Kohlmeyer became interested in an ecology of arenicolous fungi, C. maritin C. trifurcata, and showed their affinity to sand and calcareous material, but nificance of this affinity has not been discussed yet.

Joined bases of the appendages can be clearly demonstrated under the $\mathrm{pl}$ croscope as described by Johnson (1963), and these appendages remain ev germinating tubes are developed (Pl. XII-C), this differs from the fact 1 appendages of Cer. halima disappear during the germination.

It is of a distributional interest that the present species was collected $f$ coast of both Tottori and Oshoro, because this shows seemingly the influenc Tsushima Current flowing through the Tsushima Straits from south to nort the Japan Sea coast.

\section{Gnomonia longirostris CRIBB et CRIBB}

(P1. XVII, C-E)

Papers Univ. Queensland Dept. Bot. 3: 101 (1956)

Perithecia innate or partly superficial, subglobose or ampulliform, mer ceous, $100-130 \mu$ in diam., subhyaline or pale brown; neck extend above sub: cylindrical, slightly sinuous, $80-100 \mu \mathrm{long}, 30-40 \mu$ in diam. at base (Pl. 2 
D). Aparaphysate. Asci cylindro-clavate or ellipsoid-fusiform; apices thick-walled in immature asci, but thin-walled with an apical pore when matured; partly deliquescent, $60-80 \times 18-20 \mu$, 8-spored. Ascospores ellipsoidal, straight, 2-celled, with slight constriction at septa, $14-16 \times 4-7 \mu$, hyaline.

Growth on SW agar restricted, flat, pale brown to pale grey brown; reverse pale to dark brown; growth is best at $25^{\circ} \mathrm{C}$.

Hab. Surface of drift coccoanut, Tane Island, Oct., 1966 (TN-1-1); immersed bamboo panel, Shirahama, Nov., 1965 (SH-16).

Although Kohlmeyer (1960) relegated the present species to synonymy under Lignincola laevis and the striking similarity of both species was noted by JoHnson \& SPARRow (1961), the present collections are described under G. longirostris, because the CRIBB \& CRIBB's observation (1956) of the ascospore-pore was precisely repeated in the present ones (Pl. XVII-E). The Johnson \& Sparrow's consideration which suggests some anatomical difference between the two species should be accepted. Asci are partly deliquescent in maturity and the apical thickening can be seen even in the matured asci from which the ascospores are discharged. Consequently the present species is treated as a separate species in this paper.

\section{Leptosphaeria discors (SAGG. et Ellis) SAGc. et Ellis}

(Pl. XII, D; XVIII, A-B)

Michelia 2: 567 (1879)

Perithecia partially innate, subhyaline, ellipsoidal or oblong ellipsoidal; neck short, centric; dark brown to black in basal half, hyaline in upper parts; carbonaceous; with semitransparent wall; $160-250 \mu$ in diam., $260-400$ (-450) $\mu$ high; paraphyses simple (Pl. XVIII-A, B). Asci clavate or cylindrical, stipitate, bitunicate, spores discharged on dehiscence of a thick-walled apical cap, persistent, 100-160 $\times 18-22 \mu$; 8-spored. Ascospores broadly ellipsoid, usually straight, 4-celled, with constriction at septa, and cells round and hyaline, mid-cells brown or yellow-brown, $24-32 \times 10$ $13 \mu$ (P1. XII-D).

Growth on SW agar good, spreading, cottony, grey-olive colored; reverse dark olive to almost black; growth is best at $20-25^{\circ} \mathrm{C}$.

Hab. Driftwood of bamboo, Moroyose, Tottori, Oct., 1966 (148-46-3; 148-481).

Each end cell of the ascospores is hyaline and stained reddish by toluidine blue differing from mid-cells which are unstained.

\section{Leptosphaeria orae-maris LINDER}

(PI. XII, E; XVIII, C)

Barghorn \& Linder, in Farlowia 1 : 413 (1944) 
Perithecia subglobose or globose, black, with a papillate neck, mostly 200-245 $\mu$ in diam.; usually innate protruding ostiole on surface (Pl. XVIII-G). Asci clavate or cylindrical, $60-120 \times 8-10 \mu$, deliquescent; 8-spored. Ascospores broadly fusoid, straight or curved; at first 2-celled, with conspicuous constriction at septa, then become 4-celled, 18-24×4-6 $\mu$, pale brown (Pl. XII-E).

Growth on SW agar good, spreading, with brown-grey mycelium; perithecia developed; reverse dark olive; growth is equally good at $20-30^{\circ} \mathrm{C}$.

Hab. Driftwood of bamboo, Amakusa, June, 1966 (140-6-1-4); immersed test panel of Phyllostachys pubescens, Amakusa, Sept., 1966 (AM-6-1).

Though the ascospores of the present fungus are shorter than those in the original description (18-25 $\times 5-8 \mu$, by LINDER), other microscopic characters agree with the original description. This fungus was found only on the bamboo-samples.

\section{Lignincola laevis HöHNK}

(Pl. XII, F)

Veröffentl. Inst. Meeresforsch. Bremerhaven 3: 216 (1955)

Perithecia innate or superficial through erosion of substratum; globose, subglobose or oblong ellipsoidal, $250-380 \times 100-200 \mu$, hyaline or subhyaline to blackish; neck usually short, often long cylindrical, $80-160 \mu$ long, centric or eccentric, unbranched. Aparaphysate. Asci fusiform or clavate, thin-walled, persistent, 8-spored, 36-50X 10-12 $\mu$. Ascospores fusiform or ellipsoidal, 2-celled, slightly constricted at septa, 16-18 $\times 5-6 \mu$, hyaline (P1. XII-F).

Growth on SW agar good, depressed wooly, grey black; reverse darker; growth is best at $25^{\circ} \mathrm{C}$.

Hab. Driftwood of bamboo, Amakusa, June, 1966 (140-6-3; 140-6-5).

Characteristics of the growth are similar to those of MeYers' and CBS's cultures.

\section{Remispora galerita TUBAKI sp. nov}

\section{(Pl. XV, T'ext-fig. 2)}

Peritheciis immersis vel superficialibus, solitariis, globosis vel subglobosis, membranaceis, 220-280 $\mu$ diam.; muris 10-15 $\mu$ crassis; hyalinis, flavidis vel pallide fuscis; rostrie elongate cylindricis, centricis, 200-300 (-500) $\mu$ longis, ad basum 30-50 $\mu$ diam., ad apicem 20-35 $\mu$ diam. Sine paraphysibus. Ascis clavatis, mox deliquescentibus, $60-80 \times 20-30 \mu$, octosporis. Ascosporis ellipsoideis tegimentis mucosis tectis, $22-28(-30) \times(8-) 10-15 \mu$; appendiculis gelatinosis, plerumque geminatis, galeriformibusque, denique striatis.

Perithecia mostly innate, rarely superficial through erosion of substratum, solitary, globose or subglobose, membranaceous, (150-) 220-280 $\mu$ in diam.; venter 
wall is of the Medusa-type (CAvaliere, 1966); walls 10-15 $\mu$ thick; hyaline, pale yellow to pale fuscous; neck elongate cylindrical, centric, 200-300(-500) $\mu$ long, 30$50 \mu$ in diam. at base, apically $20-35 \mu$ in diam. Aparaphysate. Asci clavate, early deliquescent, $60-80 \times 20-30 \mu ; 8$-spored. Ascospores cllipsoidal, ends rounded, wall covered by a gelatinous sheath, 2-celled, without constriction at septa, guttulate, 22-28
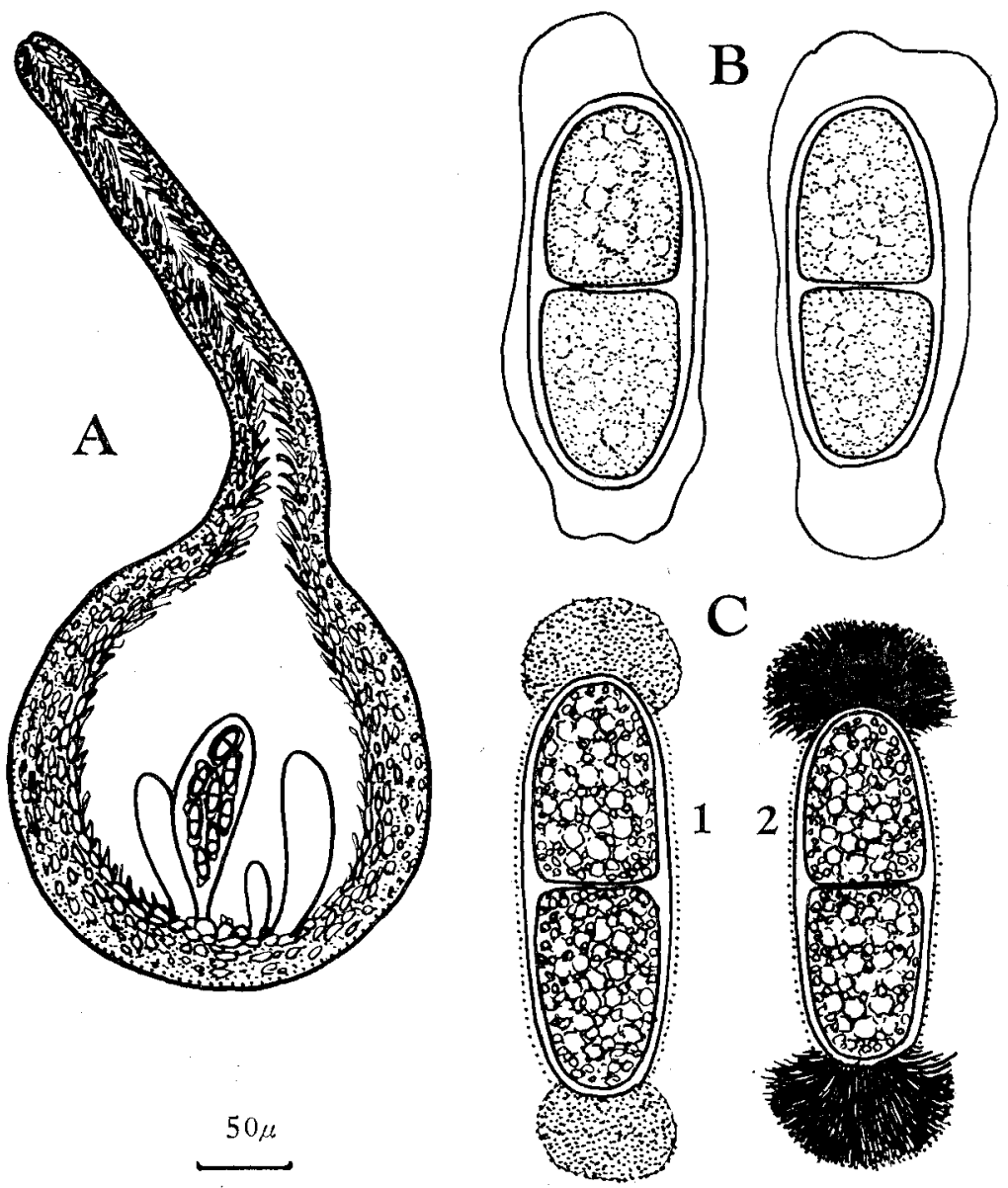

$10 \mu$

Fig. 2. Remispora galerita A: Perithecium, B: Ascospores under phase contrast, C: Ascospores stained by toluidine-blue (1) and trypan blue (2).

$(-30) \times(8-) 10-15 \mu$ (excluding appendages), hyaline; appendages gelatinous in flexuous sheath around ascospores, mostly geminate and skull-cap shape or lobed, finely striate (by trypan blue).

Growth on SW agar rather restricted, consist of flat, uneven mycelium, dark 
olive to almost black; reverse darker.

Hab. Immersed balsa wood panel, Tomioka, Amakusa, Kyushu, June, 1967 (AK-23-1). Type (Ex. Herb. IFO. 11590) in a form of a dried panel and a culture derived from the type, IFO. $8827(=\mathrm{HO}-34-3)$, are preserved in the Institute for Fermentation.

Appendages, in sheath, appear characteristically gelatinous, and the specific epithet, galerita, is derived from skull-cap shape or ear-shape of the appendage, suggestive of the wearing skull-caps. The germinated appendages appear bluish and finely striated under staining by trypan blue (Pl. XV-D) and uniformly reddish by toluidine blue (Pl. XV-E).

The spore appendage has an aspect similar to those of Remispora pilleata KoHLmEYER (1963). However, the spores of the latter species are rhomboid. By the courtesy of Dr. J. Gerloff, Botanischen Garten und Museum, Berlin-Dahlem, I had an opportunity to examine the holotype of R. pilleata Kohlmeyer (Herb. No. 914) and the clear difference between them was confirmed.

\section{Remispora ornata Johnson et Cavaliere \\ (Pl. XIII, D-E, ; VIII, D-E)}

Nova Hedwigia 6: 188 (1963)

Perithecia innate or partially superficial, globose or subglobose, membranaceous, 140-350 $\mu$ in diam., 200-300 $\mu$ high, dark fuscous or nearly black above, fading to subhyaline below, or brown throughout; neck papilliform or short cylindrical measuring 80-100 $\mu$ long (Pl. XVIII-D, E). Aparaphysate. Ascospores ellipsoidal, 2celled, hyaline, with or without constriction at septa, containing one large guttule in each cell, provided with a single, hamate or cornute, flexuous, non-gelatinous appendage at each end, and 2-4 similar equatorial ones; $18-22 \times 8-10 \mu$ (excluding appendages) (Pl. XIII-D, E).

Growth on SW agar slow, somewhat restricted, grey, with scarce mycelium; reverse dark olive to almost black with submerged mycelium in abundance; growth is best at $20-25^{\circ} \mathrm{C}$.

Hab. Driftwood and immersed test panel of Phyllostachys pubescens, Tottori, Oct., 1966 (137-9-1, 137-14-1, 148-46-3); immersed test panel of balsa and Pinus densiflora, Oshoro Bay, Hokkaido (HO-41-3, HO-43-3), Oct., 1966; Immersed test panel of Cryptomeria japonica and balsa wood, Amakusa (AK-22-1, AK-24-1), June, 1967; Balsa wood, Iwaya (155-5-2).

Appendages can be detected more clearly by toluidine blue, and those of the present fungus are similar to those of Halosphaeria appendiculata Linder, but, in the latter species, terminal appendages are gelatinous as clearly indicated in the LINDER's type material (personal communication from Dr. T.W. Johnson). The nature of the appendages was discussed in detail by KIRK (1966). 


\section{Remispora maritima LINDER \\ (Pl. XIII, G; XIX, A-B)}

BARghoorn \& Linder, in Farlowia 1: 410 (1944)

Perithecia mostly innate, completely buried within substratum, globose or subglobose, often elongate-globose, hyaline or pale yellow, membranaceous, 240-300 $\times$ 200-250 $\mu$; neck variable in length, mostly straight, cylindrical, centric or eccentric, $100-230 \mu$ long, $40-50 \mu$ in diam. at base, apically $20-24 \mu$ in diam., hyaline or pale yellow (Pl. XIX-A, B). Aparaphysate. Asci elongate-clavagte, early deliquescent; 8-spored. Ascospores ovoid or ellipsoidal, ends rounded, 2-celled, provided at each end with a pair of hyaline, stout, tapering, divergent, fairly striate, gelatinous appendages, $20-25 \times 8-10(-12) \mu$, hyaline.

Growth on SW agar more or less restricted, consist of thick aerial mycelium, olive green to dark olive; reverse darker.

Hab. Immersed test panel of balsa, Hamajima, Mihe, Nov., 1967 (MH-22-1).

Toluidine blue staining of the ascospores shows various aspects of the appendages as described by Johnson \& Cavaliere (1963) (Pl. XIII-G).

\section{Remispora quadri-remis (HöHNK) KOHLMEYER}

(Pl. XIII, B)

\section{Nova Hedwigia 2: 332 (1960)}

Perithecia mostly innate, subglobose, membranaceous, 200-400 $\times 180-300 \mu$, brown. Aparaphysate. Asci elongate-clavate, deliquescent, 50-100 ×20-40 $\mu$; 8-spored. Ascospores ovoid or ellipsoidal, end rounded, 2-celled, usually without constriction at septa, guttulate, appendaged, 22-30×10-12 $\mu$, hyaline; appendages 3-4 in number, semi-rigid, ventricose, gelatinous, divergent and recurved tapering to points, 12-20 $\mu$ long, hyaline.

Growth on SW agar good, but rather restricted, greyish olive with abundant production of submerged mycelium into agar; reverse dark olive to almost black; growth is best at $25^{\circ} \mathrm{C}$.

Hab. Immersed test panel of Cryptomeria japonica, Moroyose, Tottori, Oct., 1966 (137-7-2, 137-12-2).

These two isolates were only found on the Cryptomeria-wood panels.

This species is peculiar in its characteristic ascospore-appendages which are almost undetected under the ordinal, transmitted light but are clearly stained reddish by toluidine blue (Pl. XIII-B). Appendages of the present collection are thicker than those illustrated by Kohlmeyer (1960) and Johnson \& Claviere (1963), and each appendage is wide-ventricose. 
Sphaerulina albispiculata Tubaki sp. nov.

(Pl. XVI, Text-fig. 3)

Peritheciis immersis, globosis, subglobosis vel ovoidis, membranaceis, ostiolatis, 200-340 $\times 150-220 \mu$ diam., hyalinis vel pallide flavescentibus; rostris ellipsoideis, cylindricis vel obclavatis, villosus, albidis, 230-400 $\mu$ altis, ad basum 100-220 $\mu$

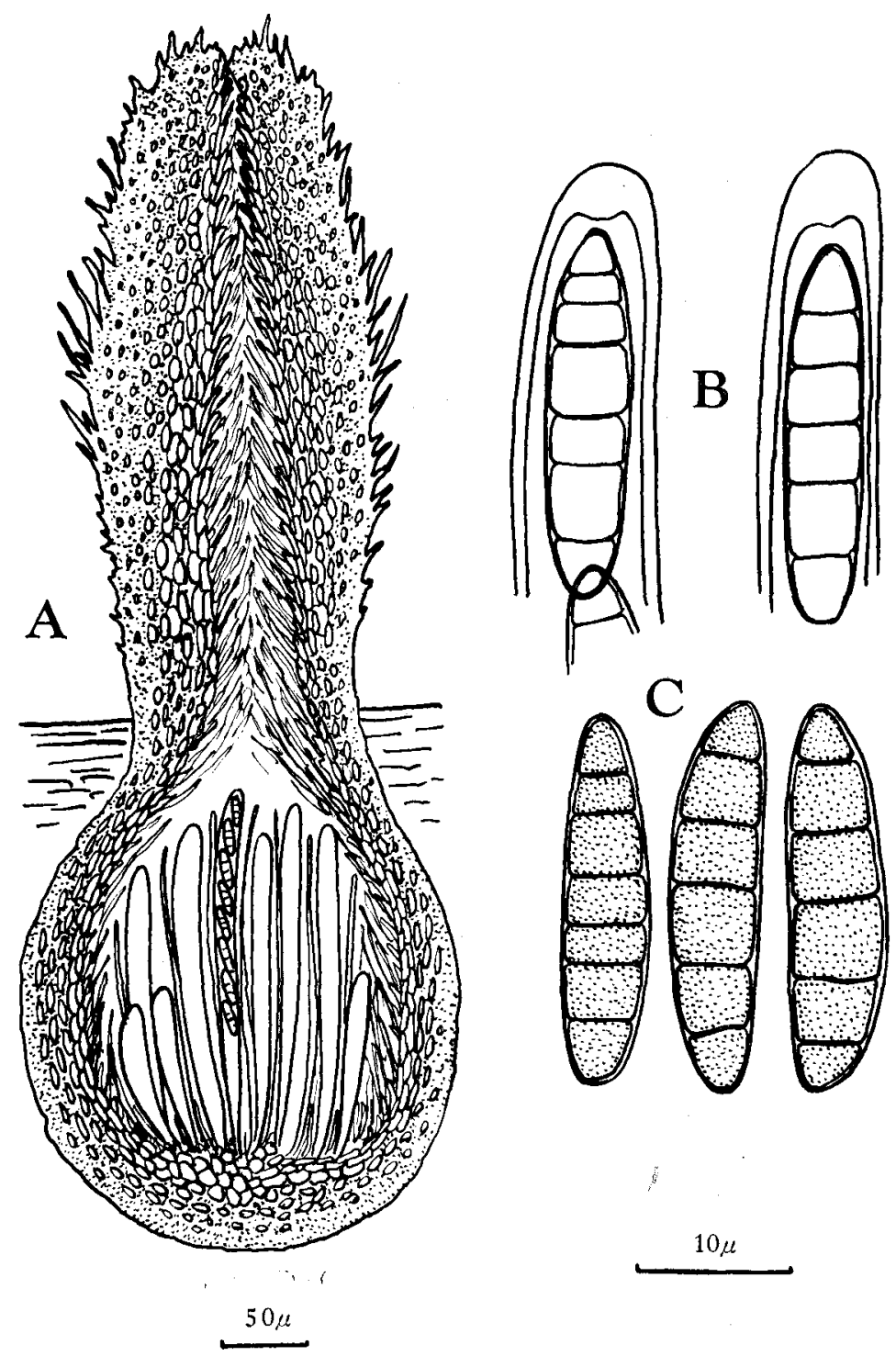

Fig. 3. Sphaerulina albispiculata A: Peritbecium, B \& C: Asci and ascospores. 
diam, substrato superantis. Asci octosporis clavatis vel cylindricis, $120-200 \times 8-10$ $\mu$. Paraphysibus. Ascosporis fusoidis vel ellipsoideis, 6-cellilaris, 25-30×5-6 $\mu$, hyalinis.

Perithecia completely innate except for thick and white neck, globose, subglobose or ovoid, membranaceous, $200-340 \times 150-220 \mu$ (excluding neck), hyaline to pale brown; neck exserted beyond substrate, thick, broadly ellipsoid, broadly cylindrical or obclavate, with slight constriction below, centric, composed of configurated cells, 230-400 $\mu$ in height, 100-220 $\mu$ in width at base, villosus with pure white bristle-like hairs at whole surface. Venter wall of perithecia is of the Medusa-type (CAvaliere, 1966). Asci clavate or cylindrical, 120-200 $\times 8-10 \mu$, 8-spored; paraphyses present. Ascospores fusoid or elliptical, 6-celled, not constricted at septa, straight or slightly curved, partially to completely biseriate, $25-30 \times 5-6 \mu$, hyaline.

Growth on SW agar markedly reduced, restricted, cartilaginous, white to pale cream colored.

Hab. Driftwood, Tane Island, Kyushu, Oct., 1966 (TN-13-1, TN-16-1). Type (Ex. Herb. IFO. 11592) and a culture derived from the type, IFO. 8828 (= TN-16-1), are preserved in the Institute for Fermentation.

The present fungus is very characteristic in that the thick and white haired neck exposed by the erosion of the wood, and also in the hyaline ascospores. The gross appearance of the exposed white neck resembles the early stage of white discomycete. Ascospore germination is also peculiar. Ascospores do not germinate on the seawater agar or other common agar media at all, while they germinate freely only on the $0.1 \%$ Na-lignosulfonic acid seawater agar medium containing $0.1 \%$ of yeast extract. Growth on the lignin-medium is better than those on malt agar, potato agar or even on the same lignin-medium prepared by distilled water instead of seawater.

Such hyalophragmous ascospores can be also found in Leptosphaeria and Metasphaeria. However, the features of pseudothecia, para-physoides and thick neck lead the present fungus to the genus Sphaerulina. Though the generic concept of Sphaerulina is slightly different from those of Saccardo (1879), Munk (1957), Linder (1944), Johnson (1956), Meyers (1957) and Kohlmeyer (1962), the present fungus is placed in the genus tentatively. It can be easily distinguished from four known species of the genus by its white, thick and haired neck. The extremely thick neck is also found in Sph. pedicellata Johnson (KoHLmeyer, 1966), but the ascospores of the latter are more longer $(40-51 \times 11-14 \mu)$. Therefore, a new species is proposed. The epithet, albispiculata, is derived from the appearance of the exposed white and haired neck.

Torpedospora radiata MEYeRs

(PI. XIII, A; XIX, C-D)

Mycologia 49: 496 (1957) 
Perithecia mostly innate, globose or depressed globose; neck elongate cylindrical, straight or irregular, centric, protruding on surface, membranaceous; $125-180 \mu$ in diam., 130-200 $\mu$ in height (excluding neck); subhyaline below, fading to pale brown to fuscous above; neck elongate, up to $200 \mu$ in length by $18-20 \mu$ in width, subhyaline to fuscous (P1. XIX-C, D). Aparaphysate. Asci elongate clavate, deliquescent very early. Ascospores elongate clavate or cylindrical and slightly tapering, 4-8- usually 7-8-celled, straight or slightly curved, one end small and abruptly swelled bearing appendages, with guttules in each cell, $36-42(-50) \times 4.5-5.8(-6.0) \mu$, hyaline, but pale orange in a liberated gelatinous masses; appendages gelatinous, acuminate, fragile, usually 3-4 in number, 20-28 $\mu$ long, easily detached.

Growth on SW agar spreading, grey to grey-brown; reverse dark brown; without production of perithecia; growth is best equally at $25-30^{\circ} \mathrm{C}$.

Hab. Driftwood, Moroyose, Tottori, Oct., 1966 (148-33-1).

Appendages can hardly be detected under the ordinal transmitted light, but clearly differentiated under the phase microscopy or under staining by toluidine blue, and are acuminate but more or less lance-shaped. Septa of the ascospores are usually 7-8 in number, differring from the original description, but other features are close to the description. Two additional collections, MH-3-2 (on immersed balsa panel, Mihe Pref., Dec., 1966) and 152-5-1 (on driftwood, Shimoda, May, 1967), are somewhat different from the above 148-33-1. Both produce the matured perithecia on SW agar in abundance. Ascospores of the former are 4-celled (Pl. XIII-A) and those of the latter are 7-8-celled. However, these slight differences are not sufficient to warrant separate species.

\section{Fungi Imperfecti}

\section{Clavariopsis bulbosa Anastasiou}

$$
\text { (Pl. XIV, A) }
$$

Mycologia 53: 11 (1961)

Conidiophores branched, septate, variable in length, 2-3 $\mu$ in diam., hyaline. Conidia are of the aleuriospore-type, apical, hyaline to pale colored, composed of basal cells and three divergent arms. Basal cell uniseptate, proximal cell bulbous, 13-15 $\times 6-8 \mu$; distal cell, 6-8 $\times 6-10 \mu$; divergent arm, mostly 2-5-septate, 28-50× 5-7 $\mu$, arising from distal cell of basal arm. Chlamydospores in a chain, globose or subglobose, $10-18 \times 7-10 \mu$, olivaceous (Pl. XIV-A).

Growth on SW agar good, rather restricted, velvety, olive-green colored; reverse darker; growth is best at $30^{\circ} \mathrm{C}$.

Hab. Drift veneer panel, Shirahama, Aug., 1966 (SH-23-1). 
This species is similar to other fresh water species of Clavariopsis in the morphological characters, but produces normal conidia aerially on agar media as described by Anastasiou (1961).

The present collection is interesting from the view point of the distribution, because it was hitherto found only from the Salton Sea, California.

\section{Humicola alopallonella Meyers et MoORE}

(Pl. XIV, B)

Amer. Jour. Bot. 47: 346 (1960)

Conidiophores slender, septate, usually unbranched, 1.5-2 $\mu$ in diam., pale brown colored, expanding into a small conidia-bearing cell. Conidia are of the aleuriosporetype, single celled, globose, ovoid, ellipsoid or pyriform, thick walled, apically on conidiophore or directly from aerial hyphae, with inflated hyphal cell at base, 8-20 $\times 6-11 \mu$, dark fuscous; inflated basal cells, $4-8 \times 4-5 \mu$, hyaline to pale fuscous ( $\mathrm{Pl}$. XIV-B).

Growth on SW agar spreading, thin, flat, grey brown to almost black; reverse darker; growth is best at $25-30^{\circ} \mathrm{C}$.

Hab. Driftwood, Tane Island, Kyushu, Oct., 1966 (TN-14-1).

As compared with the authentic strain, F-123 which was kindly offered by Dr. S.P. Meyers, several celled conidiophores giving the appearance of an elongatedacrymoid phaeophragmospore are almost lacking in the present strain, and conidia of the present strain are smaller than those of the type. Conidia of the present strain are rather regularly globose to pyriform and similar to the non-septate, normal conidia of the type. Therefore it seems better to include fungus in the present material in the above species.

\section{Monodictys pelagica (Johnson) Jones}

(Pl. XIV, G)

Trans. Brit. Mycol. Soc. 46: 138 (1963)

syn. Piricauda pelagica Johnson, in Elisha Mitchell Sci. Soc. 74: 42 (1958)

Hyphae thick walled, septate, sparingly branched, pale to dark brown, without chlamydospores, $2-2.5 \mu$ in diam. Conidia are of the aleuriospore-type, symmetrically or often asymmetrically obpyriform, muriform, with constriction at septa, 18$35(-50) \times 14-22 \mu$, nearly opaque, with pale-fuscous basal cells (Pl. XIV-C).

Growth on SW agar spreading, cottony, grey-olive colored; reverse darker; growth is best at $20-25^{\circ} \mathrm{C}$.

Hab. Immersed test panel of red pine, Oshoro Bay, Hokkaido, Oct., 1966 (HO-33-1). 


\section{Zalerion varia ANASTASIOU}

(Pl. XIV, D)

Canad. Jour. Bot. 41 : 1136 (1963)

Conidiophores simple, septate, up to $20 \times 2-3 \mu$, hyaline to pale olive colored. Conidia are of the aleuriospore-type, on effuse mycelium, 20-35 $\times 8-25 \mu$, pale to dark brown; conidial filament coiled in irregular manner, forming a tangled knot of cells; conidial cells $5-10 \times 4-8 \mu$ (Pl. XIV-D).

Growth on SW agar markedly reduced, comparatively thin, restricted, dark olive-brown, with abundant submerged mycelium; spiral of the conidia is very loose, and these conidia hardly form the spiral and are many celled strands; in old culture, primitive spirals may occur; growth is best at $25^{\circ} \mathrm{C}$.

Hab. Immersed bridge-pile (Cryptomeria japonica), Tomo, Hiroshima Pref., Oct., 1966 (MY-2-1); surface of the drift cocoanut, Tane Island, Kyushu, Oct., 1966 (TN-2-1).

This species is characteristic in its irregular spiral. Though the spiral is smaller than that of the ANASTASIOU's original description, the manner of the coils and the cultural characteristics are identical with the description.

The present species was found only from the Salton Sea.

\section{Summary}

Sixteen lignicolous marine fungi are recorded from the sea around Japan for the first records of Japanese flora, including species of Antennospora, Corollospora, Gnomonia, Leptosphaeria, Lignincola, Remispora, Sphaerulina, Torpedospora, Clavariopsis, Humicola, Monodictys and Zalerion. On the basis of taxonomic studies, the following two new species are described: Remispora galerita and Sphaerulina albispiculata.

\section{Acknowledgement}

The author gratefully acknowledges the help of the following individuals that he received during the collection of the marine fungi: Prof. T. Tокіока, Seto Marine Biological Laboratory, Kyoto University; Prof. H. Hirose and Mr. S. Еломото, Kobe University; Prof. M. Hongo, Prof. T. Hosokawa and Dr. T. Kikughr, Kyushu University; Prof. Y. Hatsuta, Tottori University; Dr. K. Inouye, Hokkaido Institute of Public Health; Dr. M. TAKI, Tanegashima Branch of the National Institute of Hygiene. The author is deeply indebted to Dr. T. Hasegawa, director of the Institute for Fermentation, for his generosity, and also to Mr. T. Iто for his assistance throughout the work.

Special thanks are also due to Dr. A.B. GrisB, University of Queensland, and 
Dr. J. Gerloff, Botanischer Garten und Museum, Berlin-Dahlem, for their having provided the type specimens.

\section{REFERENGES}

Cavaliere, A. R. 1966. Marine Ascomycetes: ascocarp morphology and its application to taxonomy. II. Nova Hedwigia 6 : 399-424.

1966. Marine Ascomycetes: ascocarp morphology and its application to taxonomy. IV. ibid. 6: 434-452.

Cribi, A. B. and CribB, J. W. 1956. Marine fungi from Queensland II. Papers, Univ. Queensland Dept. Bot. 3: 97-105.

Barghoorn, E. S. and Linder, D. H. 1944. Marine fungi: their taxonomy and biology. Farlowia 1: $395-467$.

Höнnк,W. 1954. Von den Mikropilzen in Watt und Meer. Abhandl. Naturwissenschaften Vereins, Bremen. 33: 407-429.

Johnson, T. W., Jr. 1956. Marine fungi II. Ascomycetes and Deuteromycetes from submerged wood. Mycologia 48: 841-851.

1963. Some aspect of morphology in marine Ascomycetes: Corollospora Werdermann. Nova Hedwigia 6: 83-93.

\& Sparrow, F. K., Jr. 1961. Fungi in oceans and estuaries. Cramer, Weinehim, 688 pp. \& Cavaliere, A. R. 1963. Some aspect of morphology in marine Ascomycetes: Remispora Linder. Nova Hedwigia 6: 179-198.

Kirk, P. W., Jr. 1966. Morphogenesis and microscopic cytochemistry of marine pyrenomycete ascospores. Nova Hedwigia Beiheft. 22: 50.

Kohlmeyer, J. 1960. Wood-inhabiting marine fungi from the Pacific Northwest and California. Nov Hedwigia 2: 293-343.

1962. Halophile Pilze von den Ufern Frankreichs. Nova Hedwigia 4: 389-420. - 1966. Ecological observations on arenicolous marine fungi. Zieit. Allg. Mikrobiol. 6: 95-106.

Meyers, S. P. 1957. Taxonomy of marine Pyrenomycetes. Mycologia 49: 475-528.

\& ScotT, E. 1967. Tallassiomycetes X. Variation in growth and reproduction of two isolates of Corollospora maritima. Mycologia 59: 446-455.

Munk, A. 1957. Danish Pyrenomycetes. Dansk Bot. Ark. 17: 332.

TunAki, K. 1966. Marine fungi from Japan. Lignicolous I. Trans. Mycol. Soc. Japan 7: $73-87$. 


\section{EXPLANATION OF PLATES XII-XIX}

Plate XII

A: Antennospora quadricornuta Ascospores, stained by toluidine blue $(\times 600)$. B-C: Corollospora, trifurcata B-Ascospores, stained by toluidine blue $(\times 600)$. C.-Germination of ascospores, stained by toluidine blue $(\times 1500)$. D: Leptosphaeria discors Immature and matured asci with ascospores $(\times 600)$. E: Leptosphaeria orae-maris Asci and ascospores $(\times 110)$. F: Lignincola laevis Persistent asci $(\times 110)$.

\section{Plate XIII}

A: Torpedospora radiata Four-celled ascospores $(\times 1500 ; \times 600$, stained by toluidine blue). B: Remispora quadri-remis Ascospores, stained by toluidine blue ( $X$ 600). C: Remispora maritima Ascospores, stained by toluidine blue $(\times 600)$. D-E: Remispora ornata Ascospores $(\mathrm{E}, \times 600$, stained by toluidine blue) and their germination $(\mathrm{D}, \times 600)$.

\section{Plate XIV}

A: Clavariopsis bulbosa Conidia $(\times 450)$. B: Humicola alopallonella Conidia $(\times 600)$. C: Monodictys pelagica Conidia $(\times 600)$. D: Zalerion varia Conidia $(\times 600)$.

\section{Plate XV}

Remispora galerita A: Perithecium $(\times 150)$. B-E: Ascospores $(\times 600)$. BUnstained. G-Under phase contrast. D-Stained by trypan blue. E-Stained by toluidine blue.

\section{Plate XVI}

Sphaerulina albispiculata A: Habit of perithecium on balsa wood $(\times 90$, by Ultropak). B: Perithecium $(\times 150)$. C: Perithecial wall $(\times 600)$. D: Apex of ascus $(\times 600)$. E: Germinating ascospores $(\times 450$, stained by toluidine blue $)$.

\section{Plate XVII}

A-B: Perithecia of Corollospora trifurcata, growing on sand grains (A, $\times 90$ by Ultropak; B, $\times 150)$. C-E: Perithecia of Gnomonia longirostris ( $\mathrm{C}, \times 90$ by Ultropak; $\mathrm{D} \times 150)$ and its asci with thick-walled apices $(\mathrm{E}, \times 600)$.

\section{Plate XVIII}

A-B: Perithecia of Leptosphaeria discors (A, $\times 90$ by Ultropak; B, $\times 150$ ). C: Perithecia of Leptosphaeria orae-maris $(\times 90$ by Ultropak). D-E: Perithecia of Remispora ornata $(\mathrm{D}, \times 40$ by Ultropak; $\mathrm{E}, \times 150)$.

\section{Plate XIX}

A-B: Perithecia of Remispora maritima (A, $\times 150 ; \mathrm{B}, \times 90$ by Ultropak). G-D: Perithecia of Torpedospora radiata $(\mathrm{C}, \times 90$ by Ultropak; $\mathrm{D}, \times 150)$. 
Publ. Seto Mar. Biol. Lab., XV (5), 1968

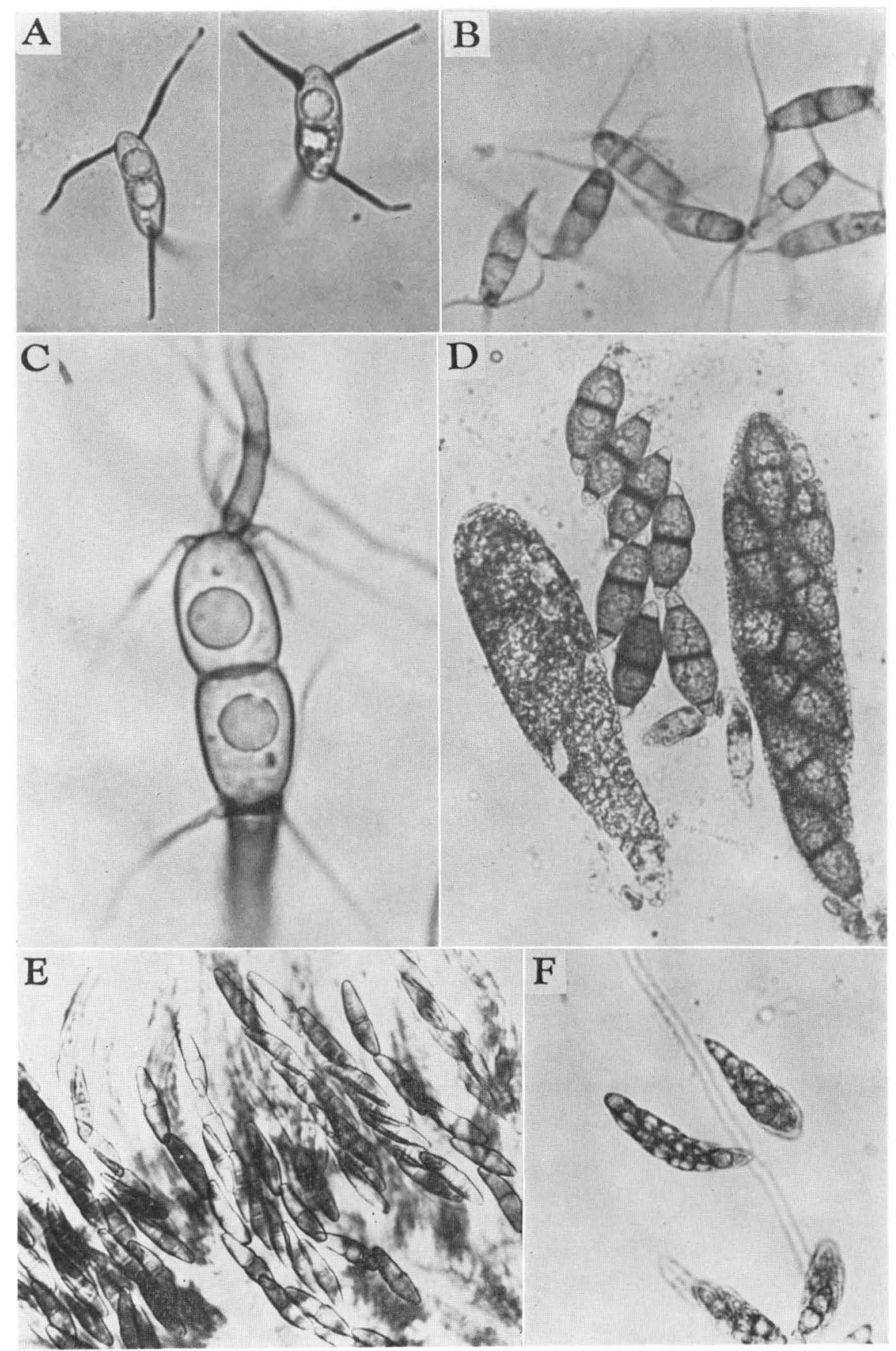

K. Tubaki: Studies on Japanese Marine Lignicolous Fungi II 
Publ. Seto Mar. Biol. Lab., XV (5), 1968.

PLATE XIII

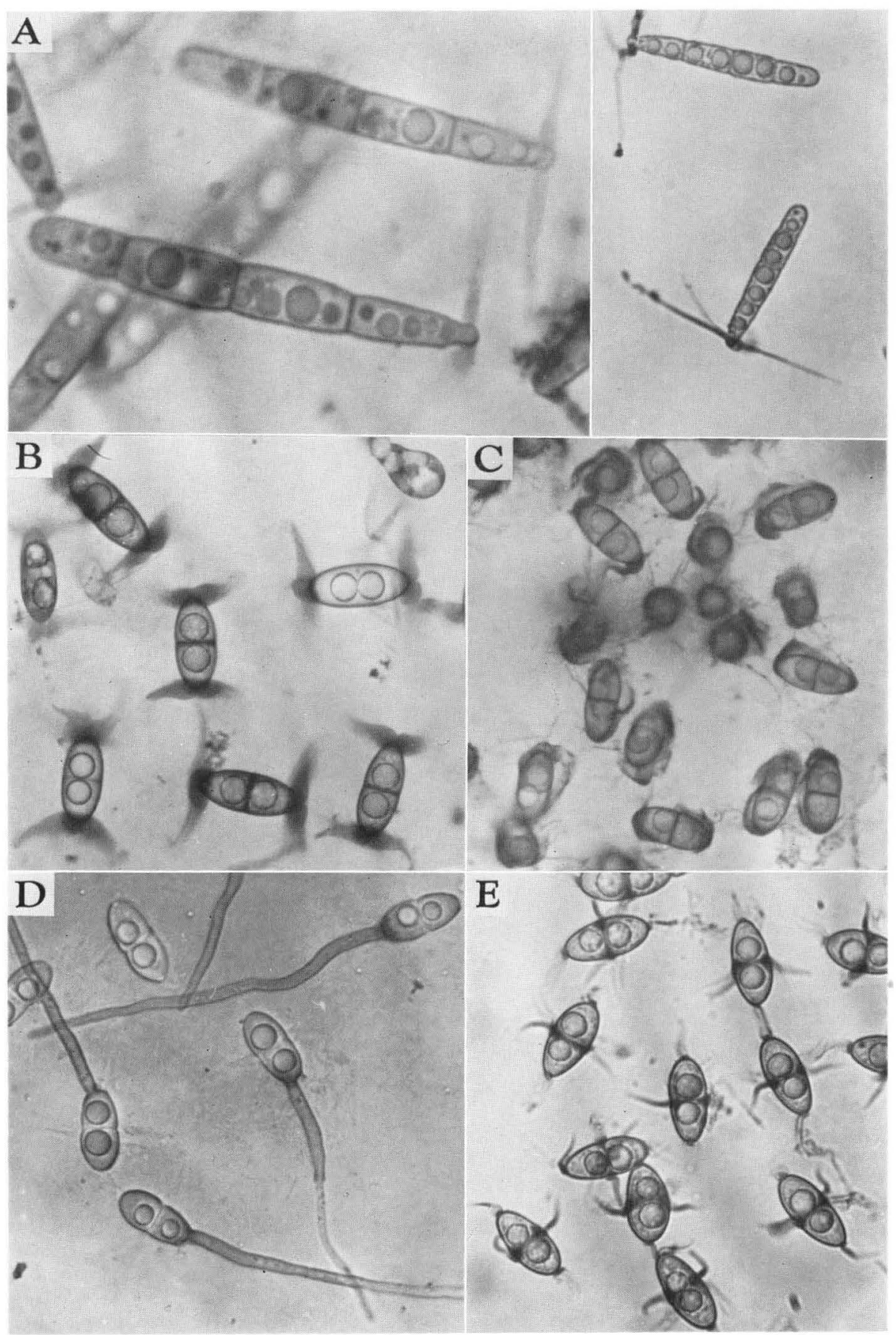

K. Tubaki : Studies on Japanese Marine Lignicolous Fungi II 
Publ. Seto Mar. Biol. Lab., XV (5), $1968 . \quad$ Plate XIV

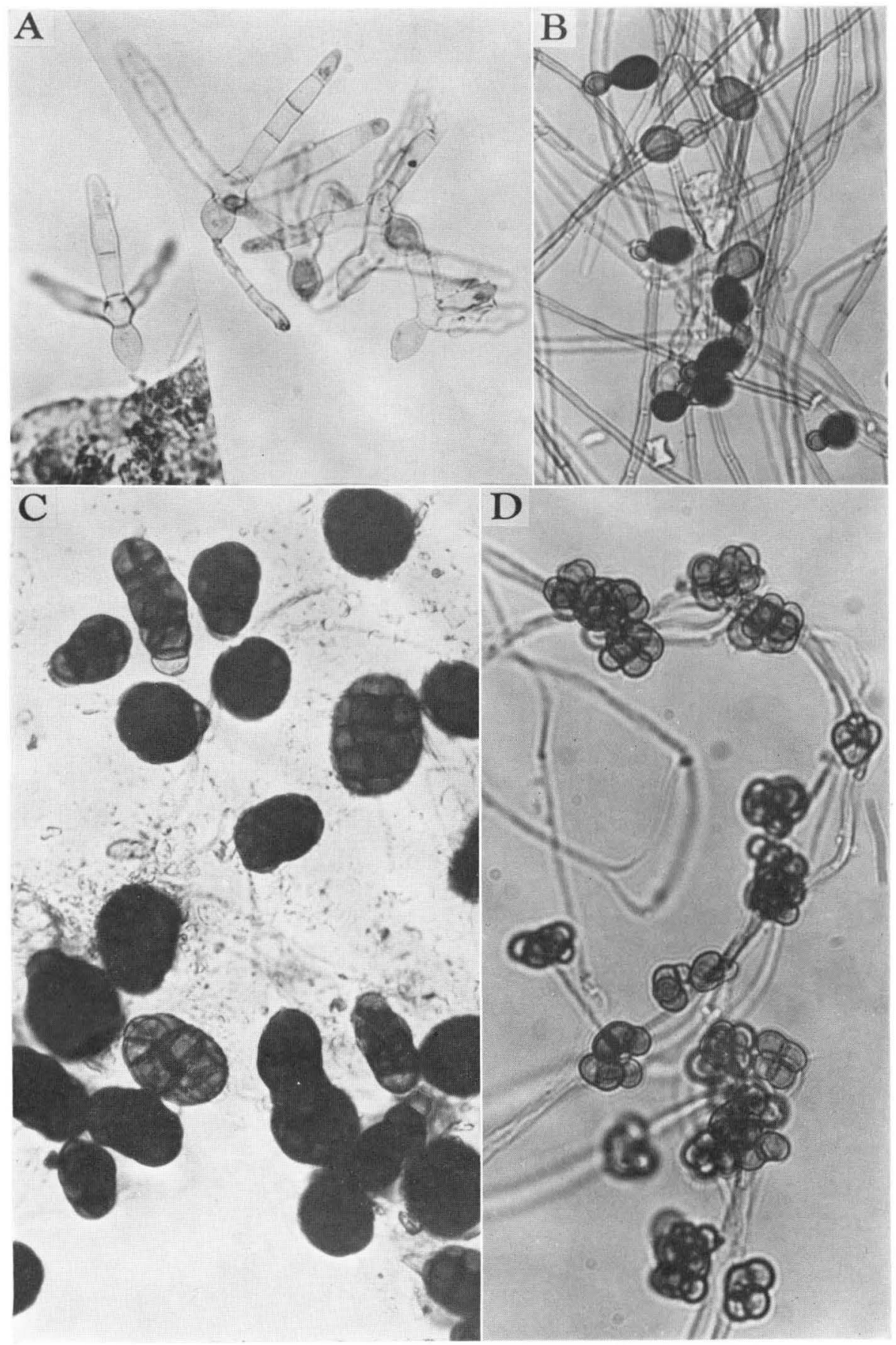

K. Tubaki: Studies on Japanese Marine Lignicolous Fungi II 
Publ. Seto Mar. Biol. Lab., XV (5), 1968.
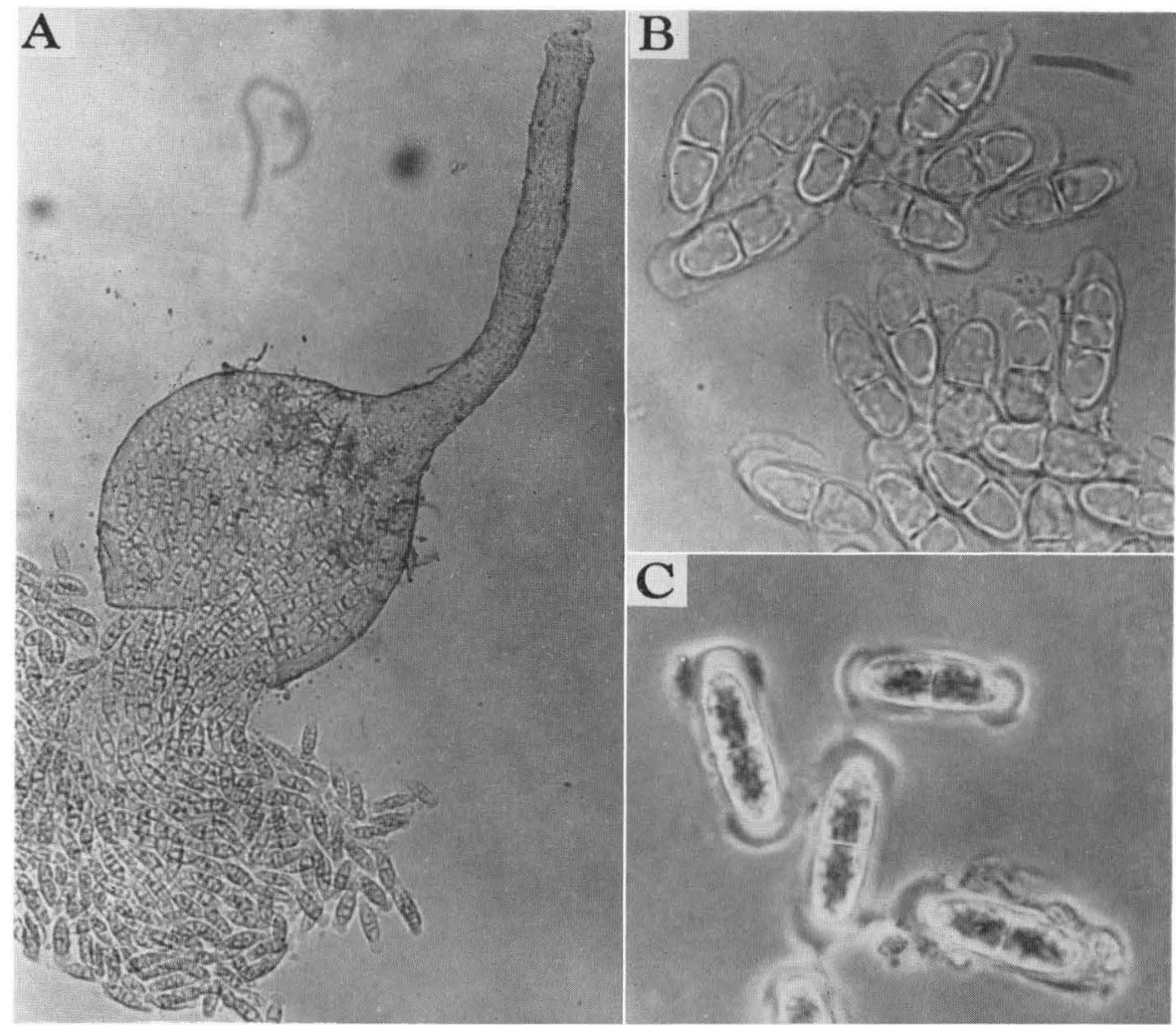

C

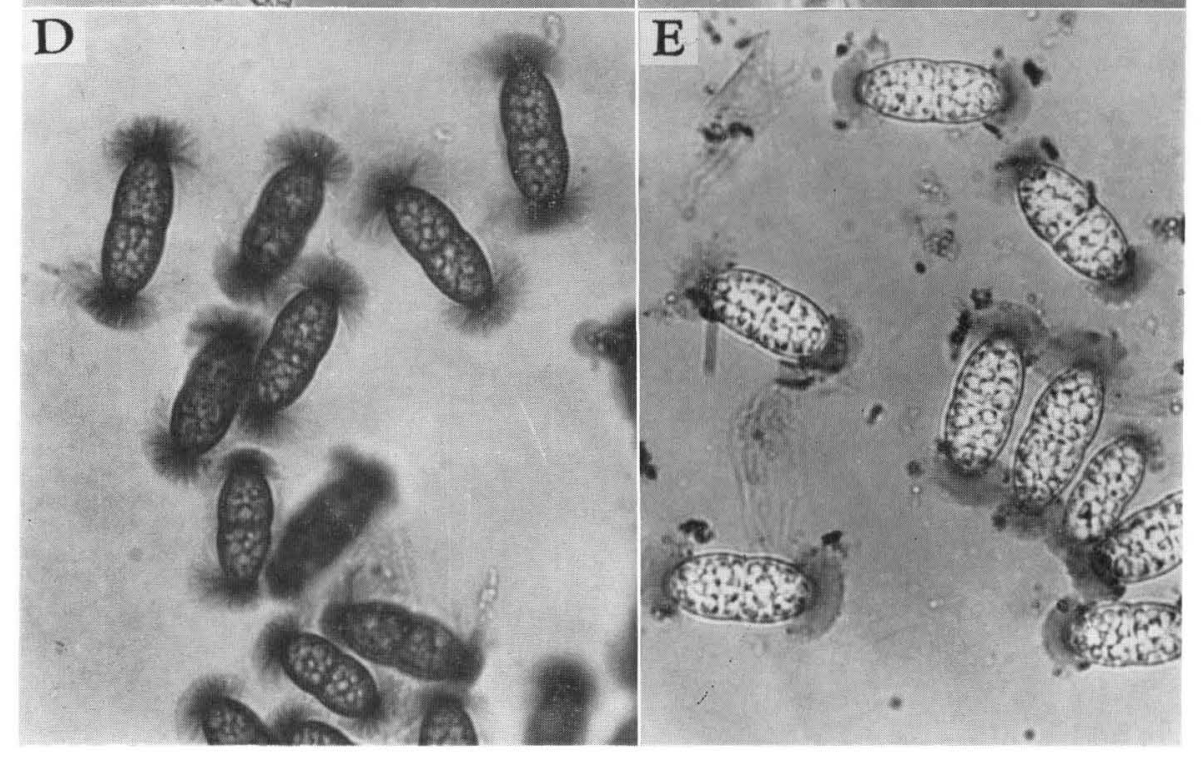

K. Tubaki: Studies on Japanese Marine Lignicolous Fungi II 
Publ. Seto Mar. Biol. Lab., XV (5), 1968.

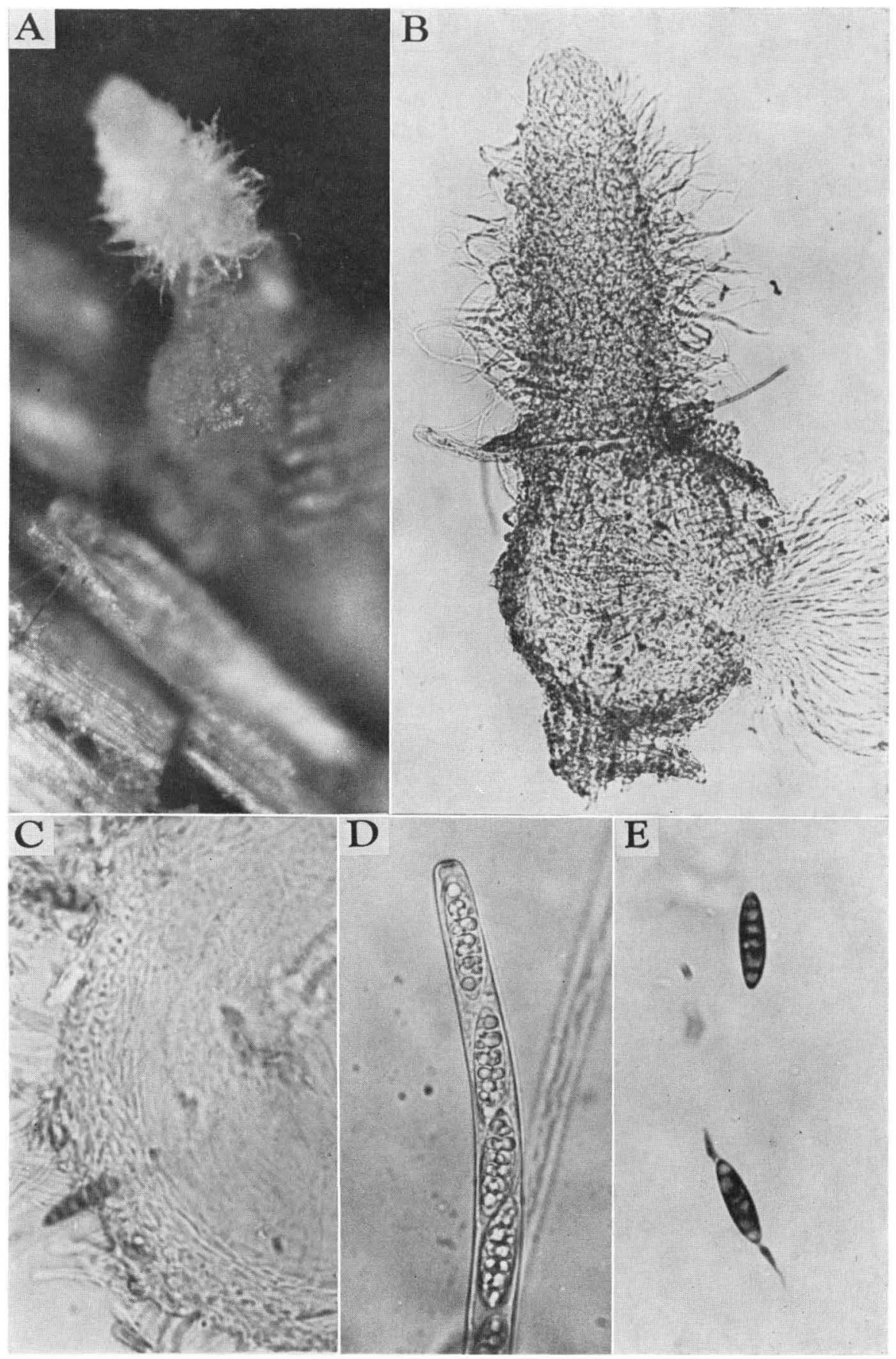

K. Tubaki: Studies on Japanese Marine Lignicolous Fungi II 
Publ .Seto Mar. Biol. Lab., XV (5), 1968.

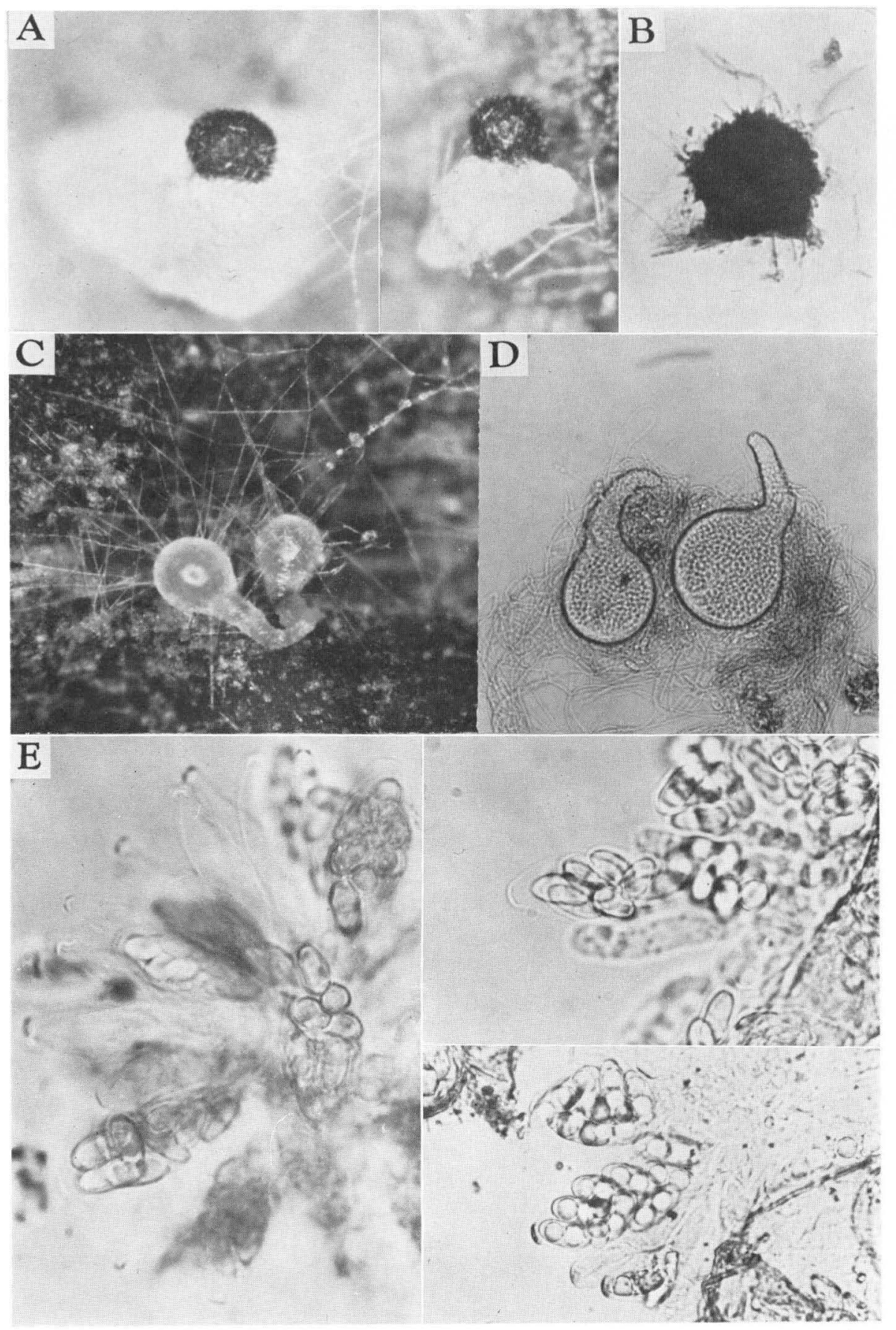

K. TubakI : Studies on Japanese Marine Lignicolous Fungi II 
Publ. Seto Mar. Biol. Lab., XV (5), $1968 . \quad$ PlATE XVIII

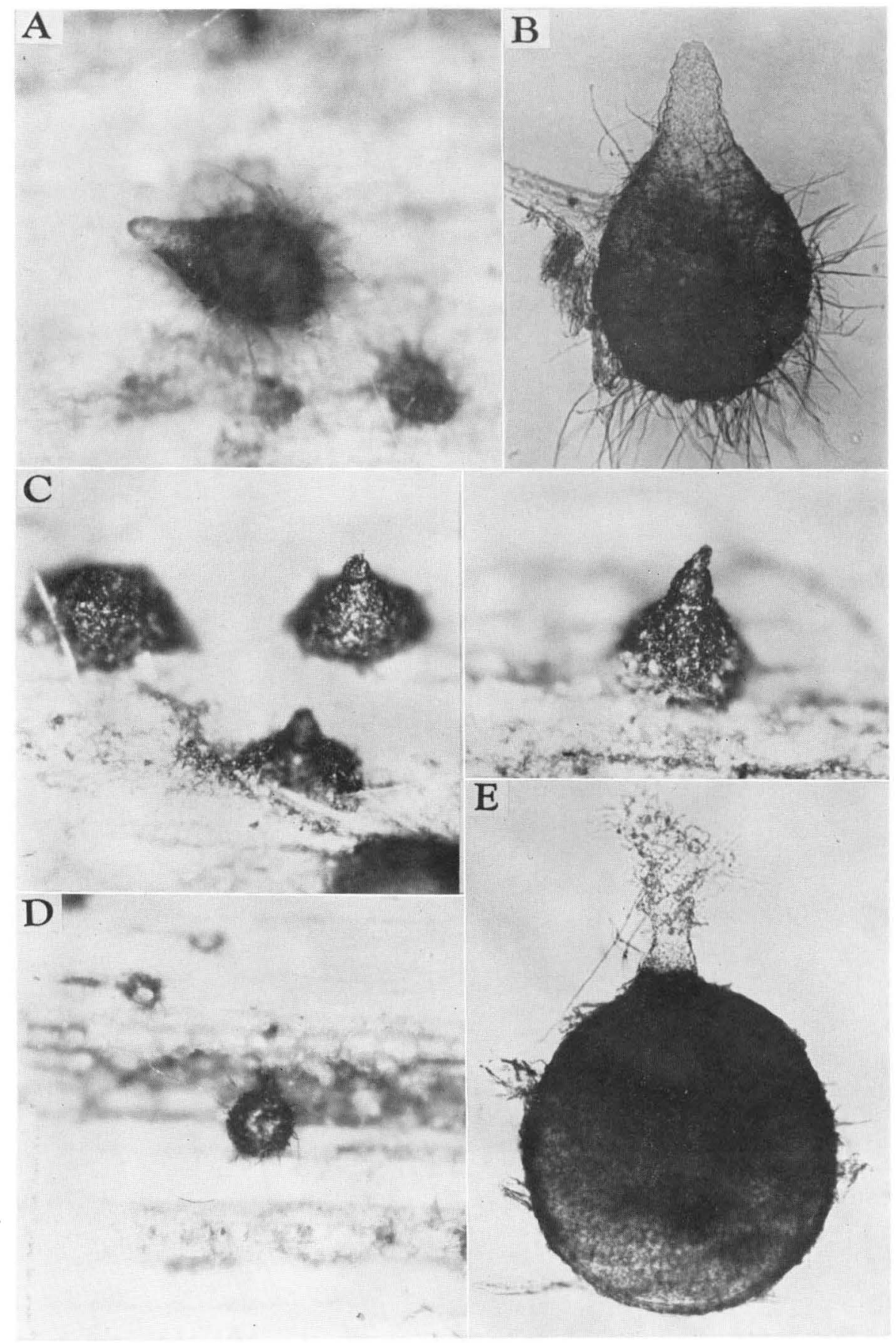

K. Tubaki : Studies on Japanese Marine Lignicolous Fungi II 
Publ. Seto Mar. Biol. Lab., XV (5), 1968.

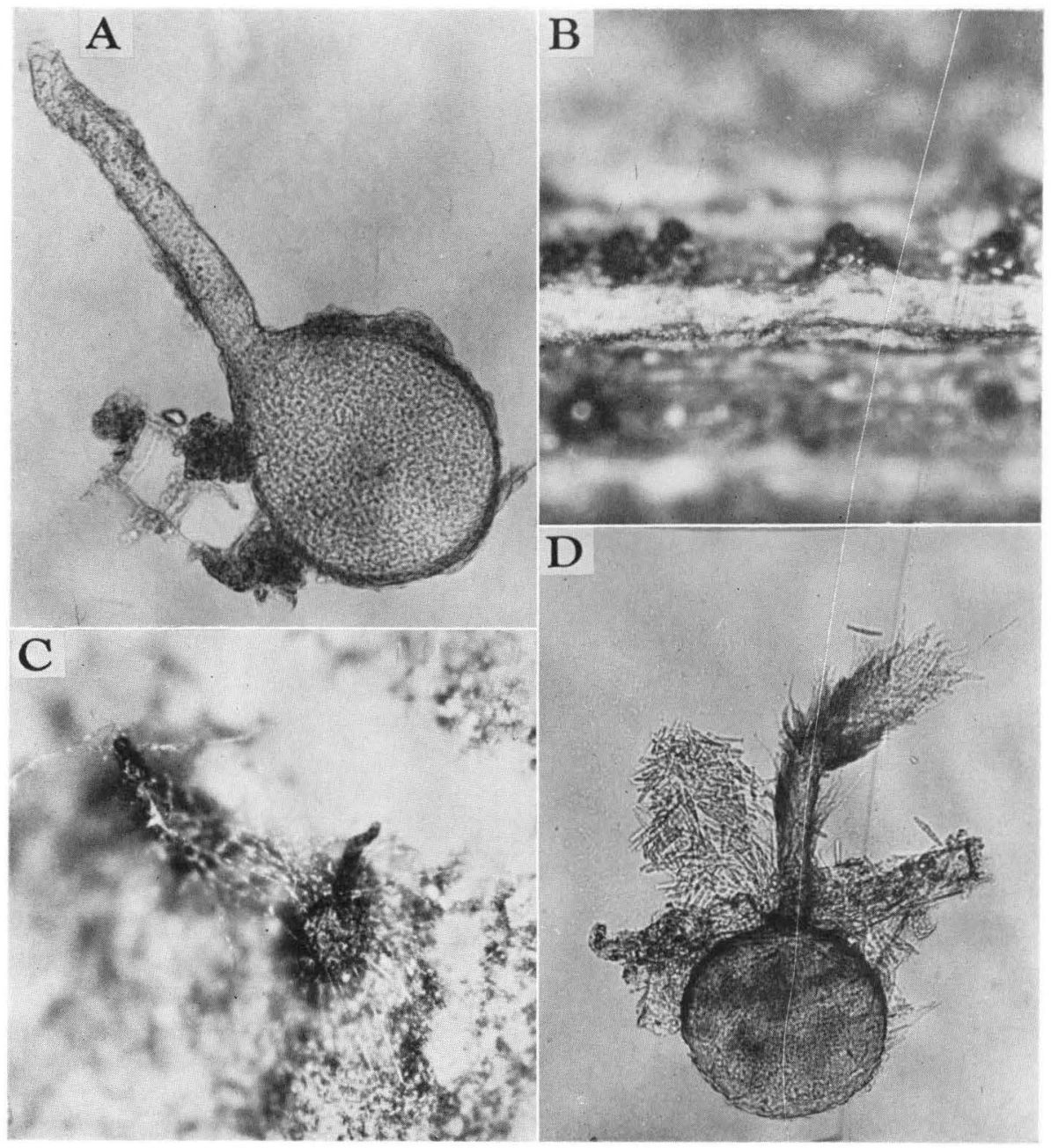

K. Tubaki : Studies on Japanese Marine Lignicolous Fungi II 